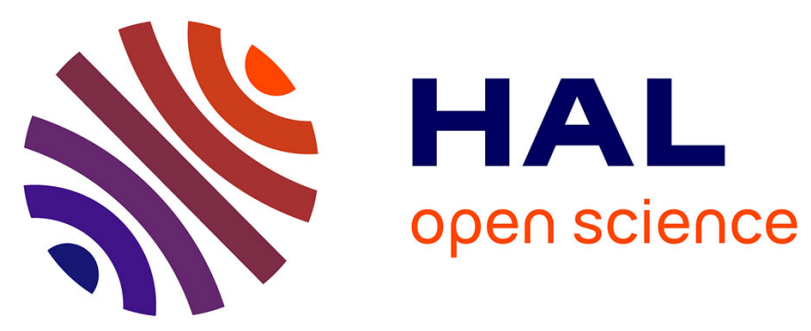

\title{
Amplification of may predict resistance to adjuvant tamoxifen in postmenopausal patients with hormone receptor positive breast cancer
}

Kirsten Vang Nielsen, Bent Ejlertsen, Sven Müller, Susanne Møller, Birgitte

B. Rasmussen, Eva Balslev, Anne-Vibeke Lænkholm, Peer Christiansen, Henning T. Mouridsen

\section{To cite this version:}

Kirsten Vang Nielsen, Bent Ejlertsen, Sven Müller, Susanne Møller, Birgitte B. Rasmussen, et al.. Amplification of may predict resistance to adjuvant tamoxifen in postmenopausal patients with hormone receptor positive breast cancer. Breast Cancer Research and Treatment, 2010, 127 (2), pp.345-355. 10.1007/s10549-010-0984-y . hal-00594479

HAL Id: hal-00594479

https://hal.science/hal-00594479

Submitted on 20 May 2011

HAL is a multi-disciplinary open access archive for the deposit and dissemination of scientific research documents, whether they are published or not. The documents may come from teaching and research institutions in France or abroad, or from public or private research centers.
L'archive ouverte pluridisciplinaire HAL, est destinée au dépôt et à la diffusion de documents scientifiques de niveau recherche, publiés ou non, émanant des établissements d'enseignement et de recherche français ou étrangers, des laboratoires publics ou privés. 


\section{Amplification of ESR1 may predict resistance to adjuvant tamoxifen in postmenopausal patients with hormone receptor positive breast cancer.}

Kirsten Vang Nielsen ${ }^{1}$, Bent Ejlertsen ${ }^{2,3}$, Sven Müller ${ }^{1}$, Susanne Møller ${ }^{3}$, Birgitte B Rasmussen ${ }^{4}$, Eva Balslev ${ }^{4}$, Anne-Vibeke Lænkholm ${ }^{5}$, Peer Christiansen ${ }^{6}$, Henning T Mouridsen ${ }^{2,3}$

${ }^{1}$ Dako AVS, Glostrup, ${ }^{2}$ Department of Oncology, Rigshospitalet, Copenhagen University Hospital, ${ }^{3}$ Danish Breast Cancer Cooperative Group (DBCG) Registry, Rigshospitalet, Copenhagen, ${ }^{4}$ Department of Pathology, Herlev University Hospital, Herlev, ${ }^{5}$ Department of Pathology, Rigshospitalet, Copenhagen University Hospital, ${ }^{6}$ Breast and Endocrine Section, Department of Surgery P, Aarhus University Hospital, Denmark

Correspondence: Kirsten Vang Nielsen, Produktionsvej 42, DK-2600 Glostrup, Denmark. Telephone: +45 4485 9494. Email: kirsten.vang@dako.com

Short title: Amplification of ESR1 and endocrine resistance in breast cancer

Keywords: ESR1, estrogen receptor, gene amplification, tamoxifen, endocrine therapy, gene aberrations, breast cancer 


\section{Abstract}

Purpose: The estrogen receptor (ER) is the target of tamoxifen, but endocrine therapies do not benefit all patients with ER positive tumors. We therefore hypothesized that copy number changes in the ESR1 gene, encoding ER, confer resistance.

Material and Methods: Within a consecutive series of ER positive, postmenopausal patients allocated to 5 years tamoxifen, we identified 61 patients with recurrence less than 4 years and 48 patients without recurrence at least 7 years after initiation of adjuvant tamoxifen. Archival tissue containing primary tumor was collected from 97 patients (89\%). Tumor samples were analyzed for ESR1 copy number changes using FISH with a probe covering the ESR1 gene at $6 \mathrm{q} 25$ and a reference probe covering the centromere of chromosome 6. The assay was validated in a material of 120 normal breast samples. Results: FISH analysis for ESR1 was successful in 91 patients (94\%). Amplification (ratio ESR1/CEN-6 22.0) was observed in 11 of 50 (22\%) patients with early recurrence, compared to two of $41(5 \%)$ patients without recurrence. The difference is statistically significant $(P=0.033)$. In both groups, two patients with $E S R 1$ deletion (ratio $E S R 1 / C E N$ $6<0.8)$ were identified. $E S R 1$ amplification was significantly associated with poor diseasefree survival $(P=0.0054)$ and overall survival $(P=0.0004)$.

Conclusion: This pilot study supports our hypothesis that ESR1 amplification is associated with a poorer outcome following adjuvant treatment with tamoxifen in ER positive early breast cancer. The study also revealed the existence of ESR1 deletions. The prognostic and predictive impact of ESR1 copy number changes needs further exploration in clinical trials. 


\section{Introduction}

The estrogen receptor (ER) is the earliest established and most widely used biomarker in breast cancer and it is recommended that the tumor ER status be determined in all breast cancer patients [1,2]. ER has both a prognostic and predictive value. ER status is a prognostic factor, but shifts from a positive prognostic factor initially to a slightly negative prognostic indicator five to six years after diagnosis [3]. ER is the target of tamoxifen. The efficacy of adjuvant endocrine therapies is associated with the presence of ER in the primary tumor [4], and patients with ER negative breast cancer are unlikely to benefit from tamoxifen. Unfortunately, endocrine therapies do not benefit all patients with ER positive tumors and in a search for explanations for this, many features of ER have been studied in the past [5], including ER $\alpha$ and ER $\beta$ protein, ER mRNA, and numerous ER cofactors, e.g. AIB1 [6,7]. Array techniques have provided information on ER target genes and response elements [8]. Also studies investigating polymorphisms [9] and mutations within the ESR1 gene that codes for $\mathrm{ER} \alpha$ have been reported.

Over a 17 years period, gene amplification of the ESR1 gene, encoding the estrogen receptor, has been the focus of very few studies $[10,11,12,13,14]$, although gene amplification is the major mechanism behind the cancer related changes of many oncogenes [15], including ERBB2 (HER2) [16], TOP2A [17], CCND1 [18] and MYC [19]. The first ESR1 gene studies were based on Southern blotting technique and showed contradictory results $[10,11]$. With more sensitive techniques, ESR1 was included in the list of possible genes located in loci that frequently undergo amplification or deletions in breast cancer [20]. Recently, the frequency of ESR1 amplifications was established [13,14] to be approximately $20 \%$ among 2000 breast cancer specimens analyzed by FISH 
(fluorescence in situ hybridization) technique, and ESR1 amplification was reported to be associated with good response to adjuvant tamoxifen treatment. The initial ESR1 FISH study [13] has led to much debate about the frequency of ESR1 amplification in breast cancer and the implication of the methodological variation for the estimation of the frequency $[21,22,23,24,25,26]$, but direct comparison of ESR1 FISH with quantitative PCR [14] showed the superiority of the FISH method for detection of these low level amplifications.

The present study [27] was initiated before publication of the study by Holst et al. [13], and our hypothesis does not take their result into account. We hypothesized that copy number changes of the ESR1 gene confer resistance to tamoxifen because amplification is an abnormal status and normal ER protein expression (ER positive status) is requisite for response to tamoxifen. We designed a study to analyze the frequency of abnormal copy number of ESR1 according to outcome in breast cancer patients having adjuvant treatment with tamoxifen. 


\section{Material and Methods}

\section{$\underline{\text { Patient samples }}$}

Tissue blocks were collected from the archives at the department of Pathology at Herlev and Roskilde Hospitals. From a nationwide, previously described cohort of 1115 Danish postmenopausal patients allocated to tamoxifen $20 \mathrm{mg}$ daily for 5 years following radical surgery from 1995 to 2006 for early hormone receptor positive breast cancer [28], we extracted a subgroup whose tumour blocks were located at one of the two participating pathology departments and who had a recurrence less than 4 years (61 patients) or were without recurrence at least 7 years after initiation of adjuvant tamoxifen (48 patients). Later revision of the patient data led to exclusion of one patient who had recurrence after 5 years from the early recurrence group and two patients where the tissue block did not contain tumor tissue; one from each recurrence group. All tumors were hormone receptor positive with more than $10 \%$ stained cells. All samples except two were analyzed on tissue microarrays (TMAs). Two samples were analyzed on whole sections. The TMAs were constructed by a technologist supervised by a pathologist (EB). A HE staining was available to identify areas of invasive breast tumor. The biomarker study was conducted according to the REMARK recommendations [29].

\section{$\underline{\text { Collection of tissue samples from normal breasts }}$}

For assay validation we analyzed ESR1 gene copy numbers in 120 samples collected consecutively and retrospectively at the department of Pathology at Herlev University Hospital from breast reduction operations with no identified malignancy. Areas of normal breast glands suitable for tissue microarray (TMA) construction were identified by a 
pathologist (EB). TMAs were constructed using Advanced Tissue Arrayer, ATA-100 (Chemicon International, Temecula, CA, USA) from formalin-fixed, paraffin-embedded normal breast tissue. Duplicate $2.0 \mathrm{~mm}$ tissue cores from each donor block were reembedded into recipient paraffin block containing 40 tissue cores.

\section{Collection of tissue samples from ER negative tumors}

To validate the observation of ESR1 deletions we identified 9 ER negative breast tumors from the tissue archives at Dako A/S which contains anonymous tissue blocks from various types of cancer. Information on some tumor characteristics was available, but patient characteristics including outcome were unknown.

\section{FISH analysis}

Samples from tumor tissue and normal tissue were analyzed for ESR1 copy number changes using FISH with a probe covering the ESR1 gene at $6 \mathrm{q} 25$ and a reference probe covering the centromere of chromosome 6. The RP11-450E24 and RP11-54K4 BAC clones (Fig. 1) that make up the ESR1 probe applied in this study covers all coding sequence of the ESR1 gene. Nearly $30 \%$ of the ESR1 probe covers up- and downstream flanking sequences including approximately $4 \%$ of the neighboring SYNE1 gene. However, as the SYNE1 overlapping part make up less than $6 \%$ of the ESR1 probe, separate amplification or deletion of SYNE1 would not be detectable by use of the ESR 1 probe. The ESR1 targeted BAC clones were labeled with Texas Red fluorochrome by Nick translation. The centromere 6 targeted references probe was based on a mixture of PNA (peptide nucleic acid) oligoes labeled with fluorescein (FITC). A mixture of alu PNA 
oligoes were used as blocking agent. The FISH protocol described below is optimized for a DNA/PNA mixture. Further details are described elsewhere [30]. Prior to FISH analysis, the slides were deparaffinized twice in Xylene for 5 minutes followed by rinse in $96 \%$ and $70 \%$ ethanol (each twice for 2 minutes). FISH was performed with Dako Histology FISH accessory kit (K5599, Dako A/S, Glostrup, Denmark) according to the manufacturer's instructions. Briefly the method consist of pretreatment for 10 minutes at $95-99^{\circ} \mathrm{C}$ in pretreatment solution followed by pepsin treatment for 10 minutes at room temperature (K5599, vial 2, RTU, pH 2.0). After denaturation at $82^{\circ} \mathrm{C}$ for 5 minutes and overnight hybridization at $45^{\circ} \mathrm{C}$, excess of probe is removed by stringent wash at $65^{\circ} \mathrm{C}$ for 10 minutes. After dehydration in ethanol, the slides are mounted in antifade with DAPI (K5599, vial 5). Figure 2 illustrates the appearance of ESR1 amplification using a Lieca DM microscope equipped with a Lieca Image System and filters for Texas Red, FITC and DAPI. The ratio was calculated as the number of signals for the gene probe divided by the number of signals for the centromere 6 reference probe. Cases were scored as ESR 1 FISH amplified when the ratio was $\geq 2.0$ and deleted when the ratio was $<0.8$.

\section{Slide evaluation}

The slides were evaluated according to the TOP2A FISH scoring guidelines (from Dako K5333 USA package insert, $1^{\text {st }}$ edition 2008.01.18, approved by the American Food and Drug Administration (FDA)). These guidelines specifically allow detection of both amplifications and deletions compared to the HER2 guidelines [31] that focus on amplifications. For a nucleus to be included in the scoring, the HER2 guidelines require that it contains signals of both colors. The TOP2A guidelines only require the presence of a green reference signal for a nucleus to be included in the scoring. The reason for this 
difference is that the truncated nuclei in cut sections of a deleted, diploid tissue sample will either contain one or zero red gene signals and omission of all nuclei with zero red signals will prevent detection of most deleted cases. A previously conducted pilot study [32] showed that two different counting methods gave identical results: Either the signals were counted in 60 nuclei or sufficient nuclei were included until a total of 60 red gene probe signals were counted along with the green reference probe signals in the same nuclei. An average of 35 nuclei was counted. The latter method has the advantage that the highest number of cells will be counted in the deleted and normal cases, while the lowest number of cells will be counted in highly amplified cases. Highly amplified cases are often obvious to identify just by looking in the microscope, but are more time demanding to evaluate if 60 nuclei have to be scored.

\section{$\underline{\text { Statistical Analysis }}$}

The DBCG Data Center collected and analyzed the data. Associations between ESR1 status and other clinicopathological characteristics were analyzed by chi-square or Fischer's exact test. P-values are two-tailed. Disease free survival (DFS) was defined as the duration of survival without invasive loco-regional recurrence, distant metastasis, contralateral breast cancer, second primary nonbreast invasive cancer or death irrespective of cause. DFS was analyzed unadjusted using the log-rank test. For multivariate analysis the Cox proportional hazards regression model was applied to assess the adjusted hazard ratio (HR) of DFS by ESR1 status, and to explore interactions. Factors included in the multivariate analyses were age, tumor size $(0-2 \mathrm{~cm},>2-5 \mathrm{~cm},>5 \mathrm{~cm})$, nodal status (0-3, 4-9, > 9 positive), histological type and grade (ductal grade I, ductal grade II, 
ductal grade III, unknowns, missing or other histological types). Statistical analyses were done with the SAS 8.2 program package.

\section{Ethics}

All data used and presented was collected and analyzed by the DBCG registry. The biological substudy was conducted according to the Helsinki declaration and approved by the Scientific Ethical Committee of the Capital Region (1H-D-2007-0034, August 17th 2007). 


\section{Results}

Archival tissue from primary tumor was retrieved from 97 of the 109 patients (89\%). FISH analysis for ESR1 was successful in 91 of the 97 patients (94\%). Patient characteristics are seen in Table 1. Patients in the early recurrence group had more positive lymph nodes $(P<0.001)$ and more tumors with higher grade $(P=0.04)$ compared to patients in the non-

recurrence group. The distribution of ESR1/CEN-6 ratios in patients without recurrence for 7 or more years compared to patients experiencing recurrence within the first 4 years is seen in Figure 3a. Ratios were found in the range of 0.50 to 3.13 . Overall $14 \%$ of the patients had amplification of the ESR1 gene. All amplifications were in the low level range with a ratio from 2.00-3.13. Nine amplifications were found in diploid tumors $(<2$ average references signals per nucleus) and 4 in triploid tumors $(<3$ average reference signals per nucleus). If no reference probe had been included most of the amplifications would have been missed as only 4 of the samples had an average of 5 or more ESR 1 gene signals/nucleus. In addition, we observed ESR1 deletion in four tumors, two in each recurrence group. The deletions were in the range of $0.50-0.76$. Three deletions were in diploid tumors and one in a triploid tumor. If no reference probe had been included only 3 deletions would have been detected.

Amplification was observed in 11 of 50 (22\%) patients with recurrence within the first four years of tamoxifen treatment, compared to two of $41(5 \%)$ patients who were free of recurrence at least 7 years after initiation of tamoxifen treatment (Table 2). The difference is statistically significant ( $P=0.033$; Fishers exact test). Compared to patients with ESR1 normal tumors, patients with ESR1 amplifications had a significant shorter disease-free ( $P=0.0054)$ and overall survival $(P=0.0004)$ as illustrated in the Kaplan-Meyer plots of Figure 4. ESR1 status is shown according to patient characteristics in Table 3 and Cox 
proportional hazards regression analysis of disease-free survival was carried out according to ESR1 status and patient characteristics. The risk of recurrence was significantly increased in the presence of $E S R 1$ amplification (HR 2.8; $P=0.0048$ ), more than 4 positive lymph nodes (HR 3.0; $P=0.0002)$ and high tumor grade (HR 3.1; $P=0.0043$ ). In a corresponding Cox analysis of overall survival ESR1 amplification (HR 3.8; $P=0.0009$ ), more than 4 positive lymph nodes (HR 3.2; $P=0.0013$ ) and high tumor grade (HR 2.3; $P=0.0321$ ) were identified as independent prognostic factors.

For assay validation we analyzed ESR1 gene copy numbers in 120 normal breast samples (Fig. $3 \mathrm{~b}$ and Fig. 5) and found neither amplifications nor deletions. In each sample 60 nuclei were evaluated. An average of 1.78 red signals representing the ESR1 genes was counted and 1.69 green signals representing the centromeric reference sequence. The ESR1/CEN-6 ratio varied from 0.96 to 1.29 with a mean of 1.06 . The ratios were distributed normally (Fig. 5) with a standard deviation of 0.04 .

To validate the observation of deletions, we performed ESR1 FISH on nine ER negative, but otherwise anonymous tissue samples. All 9 samples had ratios below 1.00 in the range from 0.61-0.96 (data not shown), and 6 of the samples had ESR1 deletion, indicating that the frequency of ESR1 deletion may be higher in an ER negative patient series. 


\section{Discussion}

The estrogen receptor (ER) is encoded by the ESR1 gene localized on chromosome 6q25.1 and copy number changes of ESR1 have only been the subject of a very limited number of studies in contrast to the intensive study of the ER protein and its cofactors [5]. The present study reports on the existence of both ESR1 amplifications and deletions. The frequency of amplification varies from $5 \%$ in a group of patients without recurrence to $22 \%$ in a group of patients with recurrence within the first four years after initiation of treatment. We found amplification in ESR1 to be a strong independent prognostic marker of poor survival in postmenopausal patients allocated to five years of tamoxifen following radical surgery for early hormone receptor positive breast cancer. The amplifications were in the low level range compared to ERBB2 (HER2) amplifications and this may be the explanation for the infrequent report of ESR1 amplifications. However, all amplifications were well outside the normal range established in 120 normal breast samples.

Genetic alterations including copy number changes are the major cancer causing mechanism [15], but amplification of ESR1 has been the focus in few studies $[10,11,12,13]$. Regulation of the estrogen receptor has primarily been studied at the protein and mRNA level and many studies have been devoted to ER as a transcription factor, e.g. ER regulation of other genes [8]. However, if the ESR1 gene itself is abnormal, in structure or copy number, it may not be capable of regulating other genes normally. In a study using Southern hybridization, no major structural rearrangements of ESR1 were identified in a series of 188 primary breast cancers [9] and subsequent studies using related techniques

for the study of polymorphisms, e.g. restriction fragment length polymorphism (RFLP) and loss of heterozygosity (LOH), have confirmed that structural changes within the ESR1 
gene are uncommon in breast cancers and do not explain differences in protein expression and ER status [11,33,34,35].

The first ESR1 gene amplification studies were based on Southern blotting technique and showed contradictory results $[10,11]$. In accordance with our observations, a study from 1990 using Southern hybridization reported low level amplification ranging from 1.6 to 3fold in 6 of 14 ER-positive tumors, while no amplification could be detected among $8 \mathrm{ER}$ negative tumors included in the study [10]. The frequency of amplification could not be confirmed in a study from 1992 [11] as only a single low level amplification among 29 ERpositive tumors was reported and the existence of ESR1 amplifications has not historically been widely appreciated [13,21]. However, the sensitivity of the Southern hybridization method may not allow detection of low level amplifications and deletions. With more sensitive techniques, ESR1 was included in the list of possible genes located in loci that frequently undergo amplification or deletions in breast cancer [20].

Two recent FISH studies [13,14] report the frequency of ESR1 amplifications to be in the range of $20-23 \%$. Our study supports the existence of ESR1 amplifications varying from $5 \%$ in the group of patients with relatively good prognosis to $22 \%$ in the poor prognosis group of patients, and amplifications were significantly associated with poor out-come following treatment with Tamoxifen. In contrast to the two previous studies, we exclusively analyzed the prognostic implications of ESR1 aberrations within an ER positive cohort, and the exclusion of ER negative patients partly explains the differences observed between studies. 
All patients in the present study were ER positive with more than $10 \%$ stained cells as demanded for receiving adjuvant endocrine treatment. We have deliberately focused on the additive role of ESR1 amplifications in a patient cohort selected for treatment by ER immunohistochemistry and have not tried to compare ER protein level with ESR1 gene status. Both the work of Holst et al. [13] and Tomita et al. [14] show that although all patients with ESR1 amplification have high protein expression (Allred score 7-8), only approximately half of the patients with high protein expression have amplifications. Thus, high protein expression apparently is not always the result of amplification, as in e.g. HER2 protein overexpression. This lack of consistence might be one of the reasons for our finding in the present work, that amplification is a predictor of resistance, with amplification reflecting gene disturbance with loss of normal function.

The initial ESR1 FISH study [13] has led to much debate about the frequency of ESR1 amplification in breast cancer and correspondences from four groups report on frequencies of only $0-10 \%$ using a variety of methods, including comparative genomic hybridization (GCH), FISH, CISH and quantitative PCR $[21,22,23,24,25,26]$. Some of the methodological debate has been resolved by the most recent study [14] that confirms the data by Holst et al. [13], but also compares the ESR1 FISH data directly with quantitative PCR data from the same patient material. The study found $22.6 \%$ ESR1 amplifications using FISH compared to $1.4 \%$ ESR 1 amplifications using q-PCR, thus providing an explanation for the reported discrepancy among the other studies $[22,23,24,25]$ and demonstrating the diminished sensitivity of the PCR-based detection of amplifications. Using FISH in an ER positive patient population we found amplification of ESR1 in 14\% but the frequency depends on the selected study samples. According to the DBCG Registry $80.8 \%$ of breast cancers were ER positive during the study period, corresponding 
to an estimated frequency of about $11 \%$ in the total population [28]. The discrepancies mimic early days of HER2 diagnostics, when different patient populations, methods, scoring guidelines and cut-off levels led to enormous debate until firm guidelines were established [31]. ESR1 amplifications seem to be at a lower level than HER2 and will thus be more difficult to detect as demonstrated by Tomita and coworkers [14]. Therefore, conflicting results must be expected when different methods are used $[10,11,12,13,14,22,23,24,25,26]$ and the majority of platforms may not detect the ESR1 amplifications [21].

The 13 amplified tumors of the present study had an average of 3-7 ESR1 signals per nucleus while Holst et al [13] reports a higher average number og signals. Using their definition of "ESR1 gain" ( $E S R 1 / C E N-6$ ratio $>1.0)$, the majority of our cases $(68=73 \%)$ would have been classified as having gain. Our assay validation showed no copy number variation among 120 normal breast samples. It is worth noting that the majority of normal samples would have been scored as having "ESR1 gain" using the criteria of ESR1 ratio $>1.0$ from Holst et al.[13]. One possible explanation for this difference is the use of different signal counting guidelines, especially for two signals not separated by the diameter of a signal. In line with HER2 scoring guidelines [31], we consider such a "duplet" signal as only one signal created by chromatin folding. Although Holst et al. [26] reports high intra-observer reproducibility, no intra-laboratory reproducibility studies have been performed, which could have revealed differences of signal counting instructions. Our assay included a reference probe to estimate the ploidy level of the samples. If only the red gene signals had been used in the assay, as in a single color FISH assay, most of the low level amplifications would have been missed and only 4 amplifications have an 
average of more than 5 gene signals/nucleus. Thus, using the cut-off criteria of Reis-Filho et al. $[25,36]$ would have reduced our frequency of amplifications to $4 \%$.

In this patient series, we also identified 4 tumors with ESR1 deletion, two in each outcome group, and confirmed the existence of deletions by analysis of nine ER negative breast tumor samples. This is the first identification of ESR1 deletions in patient samples by FISH technique, but an in vitro study [37] using simultaneous fluorescence immunophenotyping and FISH detected ESR1 deletions in four of six breast cancer cell lines. However, as no correlation to ER expression could be found, this solitary study concluded that ESR1 deletions are not the major cause of absent or reduced ER expression in breast cancer cell lines. Although the ESR1 deletions may not correlate with ER protein expression, the observation on patient samples deserves further analysis.

In summary, our data support that ESR1 amplification is a frequent feature of ER positive tumors $[13,14]$. We observe ESR1 gene amplification in $14 \%$ of the tumors, ranging from $5 \%$ in patients with superior outcome to $22 \%$ in patients with inferior outcome on adjuvant treatment with tamoxifen. The ESR1 amplifications are significantly associated with poor disease-free and overall survival, and in this respect our data disagree with recent ESR1 FISH observations [13,14]. The clinical utility of ESR1 copy number changes deserves more attention until the exact importance for patient diagnostics has been established. 


\section{Acknowledgements}

We thank Signe Lykke Nielsen for excellent technical assistance. Supported by the Danish

Research Council (Grant No. 271060542) and Danish Ministry of Internal Affairs and

Health (Grant No. 2006-12103-272). 


\section{Legends to figures}

Figure 1. Localization and coverage of the ESR1/CEN-6 probe mixture (A). The ESR1 probe covered the entire ESR1 gene and flanking regions and consisted of $2 \mathrm{BAC}$ clones (BAC RP11-450E24 and RP11-54K4) (B) localized using the UCSC Genome Browser on Human Mar. 2006 Assembly.

Figure 2 . ESR1 amplification in a breast cancer sample. In the individual filters, the red ESR1 signals $(A)$, the green centromere 6 signals $(B)$ and the DAPI counterstaining $(C)$ is seen. (D) shows the combined picture of the individual filters.

Figure 3. Distribution of $E S R 1 / C E N-6$ ratios in (A) 50 patients with early recurrence (yellow) and 41 patients recurrence free for at least 7 years (blue) and the distribution of ESR1/CEN-6 ratios (B) in 120 samples from normal breast tissue (purple).

Figure 4. Recurrence free survival (A) and overall survival (B) of patients with and without ESR1 amplifications.

Figure 5. The distribution of ESR1/CEN-6 ratios in 120 samples from normal breast tissue. 


\section{Legends to Tables}

Table 1. Patient characteristics correlated with recurrence groups.

Table 2. Distribution of tumors with ESR1 amplification and deletion among patients with early recurrence and patients with late or no recurrence.

Table 3. Patient characteristics correlated to ESR1 status. 


\section{References}

1. Harris L, Fritsche H, Mennel R, Norton L, Ravdin P, Taube S, Somerfield MR, Hayes DF, Bast RC, Jr. (2007) American Society of Clinical Oncology 2007 update of recommendations for the use of tumor markers in breast cancer. J Clin Oncol 25:5287-5312.

2. Goldhirsch A, Wood W, Gelber R, Coates A, Thurlimann B, Senn HJ, Members P (2007) Progress and promise: highlights of the international expert consensus on the primary therapy of early breast cancer 2007. Ann Oncol 18:1133-1144.

3. Bentzon N, During M, Rasmussen BB, Mouridsen H, Kroman N (2008) Prognostic effect of estrogen receptor status across age in primary breast cancer. Int $\mathrm{J}$ Cancer 122:1089-1094.

4. EBCTCG (2005) Effects of chemotherapy and hormonal therapy for early breast cancer on recurrence and 15-year survival: an overview of the randomised trials. Lancet 365:1687-1717.

5. Schiff R, Osborne CK (2005) Endocrinology and hormone therapy in breast cancer: new insight into estrogen receptor-alpha function and its implication for endocrine therapy resistance in breast cancer. Breast Cancer Res 7:205-211.

6. Osborne CK, Bardou V, Hopp TA, Chamness GC, Hilsenbeck SG, Fuqua SA, Wong J, Allred DC, Clark GM, Schiff R (2003) Role of the estrogen receptor coactivator AIB1 (SRC-3) and HER-2/neu in tamoxifen resistance in breast cancer. J Natl Cancer Inst 95:353-361.

7. Kirkegaard T, McGlynn LM, Campbell FM, Muller S, Tovey SM, Dunne B, Nielsen KV, Cooke TG, Bartlett JM (2007) Amplified in breast cancer 1 in human epidermal growth factor receptor - positive tumors of tamoxifen-treated breast cancer patients. Clin Cancer Res 13:1405-1411.

8. Lin CY, Strom A, Vega VB, Kong SL, Yeo AL, Thomsen JS, Chan WC, Doray B, Bangarusamy DK, Ramasamy A, Vergara LA, Tang S, Chong A, Bajic VB, Miller LD, Gustafsson JA, Liu ET (2004) Discovery of estrogen receptor alpha target genes and response elements in breast tumor cells. Genome Biol 5:R66.

9. Hill SM, Fuqua SA, Chamness GC, Greene GL, McGuire WL (1989) Estrogen receptor expression in human breast cancer associated with an estrogen receptor gene restriction fragment length polymorphism. Cancer Res 49:145-148.

10. Nembrot M, Quintana B, Mordoh J (1990) Estrogen receptor gene amplification is found in some estrogen receptor-positive human breast tumors. Biochem Biophys Res Commun 166:601-607.

11. Watts CK, Handel ML, King RJ, Sutherland RL (1992) Oestrogen receptor gene structure and function in breast cancer. J Steroid Biochem Mol Biol 41:529-536.

12. Schuur ER, Weigel RJ (2000) Monoallelic amplification of estrogen receptor-alpha expression in breast cancer. Cancer Res 60:2598-2601.

13. Holst F, Stahl PR, Ruiz C, Hellwinkel O, Jehan Z, Wendland M, Lebeau A, Terracciano L, Al-Kuraya K, Janicke F, Sauter G, Simon R (2007) Estrogen receptor alpha (ESR1) gene amplification is frequent in breast cancer. Nat Genet 39:655-660.

14. Tomita S, Zhang Z, Nakano M, Ibusuki M, Kawazoe T, Yamamoto Y, Iwase H (2009) Estrogen receptor alpha gene ESR1 amplification may predict endocrine therapy responsiveness in breast cancer patients. Cancer Sci 100:1012-1017.

15. Albertson DG (2006) Gene amplification in cancer. Trends Genet 22:447-455. 
16. Slamon DJ, Clark GM, Wong SG, Levin WJ, Ullrich A, McGuire WL (1987) Human breast cancer: correlation of relapse and survival with amplification of the HER2/neu oncogene. Science 235:177-182.

17. Järvinen TAH, Tanner M, Bärlund M, Borg $\AA$, Isola J (1999) Characterization of Topoisomerase lla Gene Amplification and Deletion in Breast Cancer. Genes Chromosomes Cancer 26:142-150.

18. Kirkegaard T, Nielsen KV, Jensen LB, Campbell FM, Muller S, Tovey SM, Brown S, Cooke TG, Bartlett JM (2008) Genetic alterations of CCND1 and EMSY in breast cancers. Histopathology 52:698-705.

19. Corzo C, Corominas JM, Tusquets I, Salido M, Bellet M, Fabregat X, Serrano S, Sole $F(2006)$ The MYC oncogene in breast cancer progression: from benign epithelium to invasive carcinoma. Cancer Genet Cytogenet 165:151-156.

20. Hicks J, Krasnitz A, Lakshmi B, Navin NE, Riggs M, Leibu E, Esposito D, Alexander J, Troge J, Grubor V, Yoon S, Wigler M, Ye K, Borresen-Dale AL, Naume B, Schlicting E, Norton L, Hagerstrom T, Skoog L, Auer G, Maner S, Lundin P, Zetterberg $A$ (2006) Novel patterns of genome rearrangement and their association with survival in breast cancer. Genome Res 16:1465-1479.

21. Albertson DG (2008) Conflicting evidence on the frequency of ESR1 amplification in breast cancer. Nat Genet 40:821-822.

22. Brown LA, Hoog J, Chin SF, Tao Y, Zayed AA, Chin K, Teschendorff AE, Quackenbush JF, Marioni JC, Leung S, Perou CM, Neilsen TO, Ellis M, Gray JW, Bernard PS, Huntsman DG, Caldas C (2008) ESR1 gene amplification in breast cancer: a common phenomenon? Nat Genet 40:806-807; author reply 810-802.

23. Horlings HM, Bergamaschi A, Nordgard SH, Kim YH, Han W, Noh DY, Salari K, Joosse SA, Reyal F, Lingjaerde OC, Kristensen VN, Borresen-Dale AL, Pollack J, van de Vijver MJ (2008) ESR1 gene amplification in breast cancer: a common phenomenon? Nat Genet 40:807-808; author reply 810-802.

24. Vincent-Salomon A, Raynal V, Lucchesi C, Gruel N, Delattre O (2008) ESR1 gene amplification in breast cancer: a common phenomenon? Nat Genet 40:809; author reply 810-802.

25. Reis-Filho JS, Drury S, Lambros MB, Marchio C, Johnson N, Natrajan R, Salter J, Levey P, Fletcher O, Peto J, Ashworth A, Dowsett M (2008) ESR1 gene amplification in breast cancer: a common phenomenon? Nat Genet 40:809-810; author reply 810-802.

26. Holst F, Stahl P, Hellwinkel O, Dancau AM, Krohn A, Wuth L, Heupel C, Lebeau A, Terracciano L, Al-Kuraya K, Janicke F, Sauter G, Simon R (2008) Reply to "ESR1 gene amplification in breast cancer: a common phenomenon?". Nat Genet 40:810812.

27. Ejlertsen B, Nielsen K, Rasmussen B, Balslev E, Müller S, Møller S, Mouridsen H (2007) Amplification of ESR1 may predict resistance to adjuvant tamoxifen in postmenopausal patients with hormone receptor positive breast cancer. Breast Cancer Res Treat 106:abstr 402.

28. Moller S, Jensen MB, Ejlertsen B, Bjerre KD, Larsen M, Hansen HB, Christiansen P, Mouridsen HT (2008) The clinical database and the treatment guidelines of the Danish Breast Cancer Cooperative Group (DBCG); its 30-years experience and future promise. Acta Oncol 47:506-524.

29. McShane LM, Altman DG, Sauerbrei W, Taube SE, Gion M, Clark GM (2005) Reporting recommendations for tumor marker prognostic studies (REMARK). J Natl Cancer Inst 97:1180-1184. 
30. Nielsen KV, Müller S, Poulsen TS, Gabs S, Schonau A (2004) Combined Use of PNA and DNA for Fluorescence In Situ Hybridization (FISH). In: Nielsen PE, editor. Peptide Nucleic Acids: Protocols and Applications. 2 ed. Norfolk: Horizon Bioscience. pp. 227-260.

31. Wolff AC, Hammond ME, Schwartz JN, Hagerty KL, Allred DC, Cote RJ, Dowsett M, Fitzgibbons PL, Hanna WM, Langer A, McShane LM, Paik S, Pegram MD, Perez EA, Press MF, Rhodes A, Sturgeon C, Taube SE, Tubbs R, Vance GH, van de Vijver M, Wheeler TM, Hayes DF (2007) American Society of Clinical Oncology/College of American Pathologists Guideline Recommendations for Human Epidermal Growth Factor Receptor 2 Testing in Breast Cancer. J Clin Oncol 25:118-145.

32. Olsen KE, Knudsen H, Rasmussen BB, Balslev E, Knoop A, Ejlertsen B, Nielsen KV, Schonau A, Overgaard J (2004) Amplification of HER2 and TOP2A and deletion of TOP2A genes in breast cancer investigated by new FISH probes. Acta Oncol 43:35-42.

33. Andersen Tl, Heimdal KR, Skrede M, Tveit K, Berg K, Borresen AL (1994) Oestrogen receptor (ESR) polymorphisms and breast cancer susceptibility. Hum Genet 94:665-670.

34. Yaich L, Dupont WD, Cavener DR, Parl FF (1992) Analysis of the Pvull restriction fragment-length polymorphism and exon structure of the estrogen receptor gene in breast cancer and peripheral blood. Cancer Res 52:77-83.

35. Otis CN, Krebs PA, Albuquerque A, Quezado MM, San Juan X, Sobel ME, Merino MJ (2002) Loss of heterozygosity of p53, BRCA1, VHL, and estrogen receptor genes in breast carcinoma: correlation with related protein products and morphologic features. Int J Surg Pathol 10:237-245.

36. Drury S, Lambros M, Marchio C, Johnson N, Salter J, Levey P, Fletcher O, Peto J, Reis-Filho J, Dowsett M. Gene copy number variability of oestrogen receptor alpha in breast cancer; 2007. Breast Cancer Res Treat 106. pp. (abstr 404).

37. Zhang Y, Siebert R, Matthiesen P, Harder S, Theile M, Scherneck S, Schlegelberger B (2000) Feasibility of simultaneous fluorescence immunophenotyping and fluorescence in situ hybridization study for the detection of estrogen receptor expression and deletions of the estrogen receptor gene in breast carcinoma cell lines. Virchows Arch 436:271-275.

\begin{tabular}{|l|l|c|c|c|l|}
\hline Parameter & & $\begin{array}{c}\text { All } \\
\text { patients }\end{array}$ & $\begin{array}{c}\text { Patients } \\
\text { without } \\
\text { recurrence } \\
\text { more than 7 } \\
\text { years }\end{array}$ & $\begin{array}{c}\text { Patients } \\
\text { with } \\
\text { recurrence } \\
<4 \text { years }\end{array}$ & $\begin{array}{l}\text { Test for no } \\
\text { difference } \\
\text { between } \\
\text { groups }\end{array}$ \\
\hline & & $\mathrm{N}=91$ & $\mathrm{~N}=41$ & $\mathrm{~N}=50$ & $\mathrm{p}$-value \\
\hline Age & Mean & & 61.7 & 61.2 & 0.76 \\
& (range) & & $\begin{array}{c}(48-72) \\
(50-76)\end{array}$ & 6.9 & \\
\hline Age groups & SD-59 years & 35 & 15 & 20 & 0.47 \\
\cline { 2 - 6 } & $60-69$ years & 42 & 18 & 24 & \\
\hline
\end{tabular}




\begin{tabular}{|c|c|c|c|c|c|}
\hline & $>70$ years & 14 & 8 & 6 & \\
\hline \multirow[t]{2}{*}{ Tumor size } & $0-20 \mathrm{~mm}$ & 35 & 18 & 17 & 0.48 \\
\hline & $>20 \mathrm{~mm}$ & 54 & 22 & 32 & \\
\hline \multirow{3}{*}{$\begin{array}{l}\text { Histological } \\
\text { type }\end{array}$} & Inv Ductal & 75 & 34 & 41 & 0.71 \\
\hline & Inv lobular & 15 & 7 & 8 & \\
\hline & Inv other & 1 & 0 & 1 & \\
\hline \multirow{5}{*}{$\begin{array}{l}\text { Grade } \\
\text { (only for } \\
\text { ductal type) }\end{array}$} & I & 20 & 16 & 4 & 0.04 \\
\hline & II & 40 & 15 & 25 & \\
\hline & III & 14 & 2 & 12 & \\
\hline & Unknown & 3 & 1 & 2 & \\
\hline & Missing & 14 & 7 & 7 & \\
\hline \multirow[t]{2}{*}{ HR status } & Pos & 87 & 38 & 49 & 0.32 \\
\hline & Neg/unknown & 4 & 3 & 1 & \\
\hline \multirow{2}{*}{ Nodal status } & Pos & 85 & 39 & 46 & 0.69 \\
\hline & Neg & 6 & 2 & 4 & \\
\hline \multirow{3}{*}{$\begin{array}{l}\text { No. of } \\
\text { positive } \\
\text { lymph nodes }\end{array}$} & 0 & 6 & 2 & 4 & $<0.001$ \\
\hline & $1-3$ & 49 & 31 & 18 & \\
\hline & $>4$ & 36 & 8 & 28 & \\
\hline \multirow{3}{*}{$\begin{array}{l}\text { No. of lymph } \\
\text { nodes } \\
\text { analyzed }\end{array}$} & $1-4$ & 1 & 1 & 0 & 0.83 \\
\hline & $5-9$ & 12 & 5 & 7 & \\
\hline & $>10$ & 78 & 35 & 43 & \\
\hline
\end{tabular}

\begin{tabular}{|l|c|c|c|c|}
\hline & $\begin{array}{c}\text { ESR1 } \\
\text { amplification }\end{array}$ & $\begin{array}{c}\text { ESR1 } \\
\text { normal }\end{array}$ & $\begin{array}{c}\text { ESR1 } \\
\text { deletion }\end{array}$ & Total \\
\hline Patients with recurrence within 4 years & $11(22 \%)$ & $37(74 \%)$ & $2(4 \%)$ & 50 \\
\hline Patients without recurrence for 7 years & $2(5 \%)$ & $37(90 \%)$ & $2(5 \%)$ & 41 \\
\hline Total & $13(14 \%)$ & $74(81 \%)$ & $4(5 \%)$ & 91 \\
\hline
\end{tabular}




\begin{tabular}{|c|c|c|c|c|c|}
\hline Parameter & & All patients & $\begin{array}{c}\text { Patients } \\
\text { without } \\
\text { ESR1 } \\
\text { amplification } \\
\mathrm{N}=78\end{array}$ & $\begin{array}{c}\text { Patient with } \\
\text { ESR } 1 \\
\text { amplification } \\
\mathrm{N}=13\end{array}$ & $\begin{array}{l}\text { Test for no } \\
\text { difference } \\
\text { between } \\
\text { groups } \\
\text { p-value }\end{array}$ \\
\hline Age (cont) & $\begin{array}{l}\text { Mean } \\
\text { (range) } \\
\text { SD }\end{array}$ & & $\begin{array}{c}61.0 \\
(48-74) \\
6.6\end{array}$ & $\begin{array}{c}63.8 \\
(50-76) \\
8.8\end{array}$ & 0.17 \\
\hline \multirow[t]{3}{*}{ Age (group) } & $18-59$ years & 35 & 31 & 4 & 0.26 \\
\hline & $60-69$ years & 42 & 37 & 5 & \\
\hline & $>70$ years & 14 & 10 & 4 & \\
\hline \multirow[t]{2}{*}{ Tumor size } & $0-20 \mathrm{~mm}$ & 35 & 29 & 6 & 0.54 \\
\hline & $>20 \mathrm{~mm}$ & 54 & 47 & 7 & \\
\hline \multirow[t]{2}{*}{$\begin{array}{l}\text { Histological } \\
\text { type }\end{array}$} & $\begin{array}{l}\text { Inv Ductal / } \\
\text { Inv other }\end{array}$ & 76 & 64 & 12 & 0.45 \\
\hline & Inv lobular & 15 & 14 & 1 & \\
\hline \multirow{2}{*}{\begin{tabular}{|l|} 
Grade (only \\
for ductal \\
type)
\end{tabular}} & I+ unknown & 37 & 33 & 4 & 0.55 \\
\hline & II +III & 54 & 45 & 9 & \\
\hline \multirow[t]{2}{*}{ HR status } & Pos & 87 & 75 & 12 & 0.47 \\
\hline & \begin{tabular}{|l|} 
Neg/unknown \\
\end{tabular} & 4 & 3 & 1 & \\
\hline \multirow[t]{2}{*}{ Nodal status } & Pos & 85 & 74 & 11 & 0.20 \\
\hline & Neg & 6 & 4 & 2 & \\
\hline \multirow{3}{*}{\begin{tabular}{|l|} 
No. of \\
positive \\
lymph nodes
\end{tabular}} & 0 & 6 & 4 & 2 & 0.80 \\
\hline & $1-3$ & 49 & 44 & 5 & \\
\hline & $>4$ & 35 & 30 & 6 & \\
\hline \multirow{3}{*}{\begin{tabular}{|l|} 
No. of lymph \\
nodes \\
analyzed
\end{tabular}} & $1-4$ & 1 & 1 & 0 & 0.12 \\
\hline & $5-9$ & 12 & 12 & 0 & \\
\hline & $>10$ & 78 & 65 & 13 & \\
\hline
\end{tabular}


